\title{
PERGESERAN MAKNA PRIYAYI DALAM NOVEL PARA PRIYAYI KARYA UMAR KAYAM
}

\author{
Rudi Ekasiswanto \\ Fakultas Ilmu Budaya Universitas Gadjah Mada Yogyakarta \\ Jln. Sosiohumaniora, Bulaksumur, Yogyakarta \\ Email: rudilada13@yahoo.com
}

\begin{abstract}
Abstrak
Penelitian ini bertujuan mengetahui makna priayi dan pergeseran makna priayi dalam Para Priyayi karya Umar Kayam. Teori yang digunakan dalam penelitian ini adalah teori hegemoni Gramsci. Metode penelitian yang digunakan adalah metode deskriptif dan analisis. Metode deskriptif digunakan untuk mendeskripsikan novel Para Priyayi dari aspek sosialnya dan metode analisis digunakan untuk menganalisis Para Priyayi dengan teori Hegemoni Gramsci. Para Priyayi mengandung nilai-nilai priayi dan pergeseran makna priyayi Jawa. Selain itu, nilai yang disusupkan pengarang, yakni Umar Kayam sebagai budayawan, akademisi, sastrawan, orang Jawa, orang pemerintahan juga memberikan pandangan tersendiri. Munculnya berbagai macam pandangan tersebut tentu saja membentuk dan mengakibatkan suatu pertarungan nilai yang ada dalam masing-masing tokoh cerita. Dalam proses pertarungan nilai itu, diduga terdapat negosiasi-negosiasi antarnilai. Hal itu terlihat dengan terjadinya mobilitas strata wong cilik menuju priayi. Proses tersebut dapat terjadi tentunya karena terdapat proses negosiasi antara wong cilik dengan priayi seperti yang terjadi pada tokoh Lantip dan Sastrodarsono ataupun antarpriayi itu sendiri. Proses-proses semacam ini terus dilakukan hingga mencapai konsensus dan kebenaran bersama dan menyebabkan persepsi terhadap konsep priayi pada masing-masing tokohnya bergeser.
\end{abstract}

Kata kunci : priayi, wong cilik, transformasi nilai, konsensus, negosiasi, hegemoni

\begin{abstract}
This study aims to determine the meaning of priyayi and its shift in Umar Kayam's Para Priyayi. The theory used in this study is the theory of hegemony Gramsci. The method used is descriptive and analytical methods. Descriptive method is used to describe the social aspects of novel Para Priyayi, while analytical methods is used to analyze novel Para Priyayi combining hegemony Gramsci. Para Priyayi containing values and meanings shift of Javanese noble. In addition, the values infiltrated by the author; Umar Kayam as humanists, academics, writers, the Javanese, also gives hiss own view. The emergence of multiple views, of course, establishes and leads a fight existing value of each character in the story. The process happen allegedly contained negotiation among values. It is seen in moving process of bumble class toward noble class. The process of negotiation among characters is represented in figures Sastrodarsono and Lantip or the fights among people in noble class their self. Such processes continue to be made to reach consensus and truth together.
\end{abstract}

Keywords: priyayi, the bumble, the transformation of values, concencuss, negotiation, and hegemonic analysis

\section{Pendahuluan}

Novel Para Priyayi (PP) melukiskan problem-problem sebuah keluarga dari waktu ke waktu, peristiwa, mobilitas sosial, bergerak dari masyarakat berdasarkan status sosial (priyayi) ke masyarakat kelas pegawai gupermen (Pegawai Negeri) dari tahun-tahun sekitar 1910-1967-an. Dengan kata lain, novel PP lebih dari segalanya berbicara tentang perubahan. Perubahan dari wong cilik ke priayi, dari priayi ke pegawai negeri, dari kota kecil (Wanagalih) ke kota besar (Yogyakarta, Jakarta).

Para priayi dalam PP menjadi locus, pentasan, di pusat yang lain, tempat kekuasaan itu bermain dan dipermainkan dari suatu pusat yang lain, sambil sesekali lingkungan priayi itu sendiri menjadi pusat kecil permainan kekuasaan lokal. Produktivitasnya tidak tinggi dan tidak selalu efektif, tetapi bisa dimanfaatkan, meskipun di dalam novel PP ditunjukkan bahwa hampir tidak bisa dimanipulasi oleh pusat-pusat lokal itu demi kepentingan lokal.

PP tidak membahas suatu yang berlangsung di pusat-pusat kekuasaan (Yogyakarta, Jakarta, Solo), tetapi novel ini lebih memilih suatu tempat yang kecil dan tidak 
menentukan perannya dalam kancah perubahan politik ialah Wanagalih. Novel ini juga tidak memilih suatu strata sosial tinggi di dalam dunia priayi yang mewakili mereka yang menentukan segala-galanya, yang berperan untuk mengubah masyarakat, tetapi stata rendah ialah guru. Strata ini paling bawah dalam tingkatan priayi, tetapi strata yang relatif paling baru. Strata yang memegang peran sangat penting terutama dalam perubahan sosial bermediakan pendidikan.

Adalah sebagai budayawan dan sastrawan, Umar Kayam merupakan salah satu dari sekian banyak pengarang karya sastra di Indonesia yang namanya harus diperhitungkan. Karyakaryanya banyak menghiasi media massa. Pembaca seringkali disajikan berbagai jenis esaiesai budaya ala Umar Kayam, cerita pendeknya penuh falsafah ataupun novel-novelnya yang bernafas dongeng etnografis Jawa bergaya khas Umar Kayam. Karya-karyanya tersebut Sri Sumarah dan Bawnke (kumpulan cerpen, 75), Seribu Kunang-Kunang di Manhattan (kumpulan cerpen, 1972), Mangan Ora Mangan Kumpul (kumpulan esai, 1990), Sugib Tanpo Bondo (1992), Madep Ngalor Sugih Madep Ngidul Sugih (1993), Para Priyayi (Novel, 1995), Jalan Menikung: Para Priyayi II (Novel, 1999), dan masih banyak karya yang berupa kolom-kolom budaya ala Umar Kayam.

Pengarang yang lahir di Ngawi, Jawa Timur, pada 30 April 1932 ini berprofesi sebagai guru besar di Fakultas Sastra Universitas Gadjah Mada, Yogyakarta. Melalui gambaran geografis tersebut dapat diketahui ruanglingkup kehidupan Umar Kayam adalah Jawa. Hal itu berkaitan erat dengan karya-karya yang dihasilkannya yang selalu berhubungan dengan budaya Jawa. Dengan demikian, bentuk karya yang telah dihasilkan oleh Umar Kayam merupakan wujud pemahaman, pengabstraksikan, dan pandangan dunia pengarang terhadap kehidupan seharihari budaya Jawa.

Karya-karya Umar Kayam tersebut mendapat resepsi dan apresiasi dari akademisi maupun pembaca pada umumnya. Hal itu terlihat dengan adanya esai, makalah, dan skripsi yang membahas karya-karyanya. Salah satu buku kumpulan esai yang mengkaji karyakarya Umar Kayam ini berjudul Umar Kayam dan Jaring Semiotik (1998). Selain itu, terdapat pula buku kumpulan esai lain yang berjudul Umar Kayam Luar Dalam (2005). Buku ini tidak hanya membahas karya-karyanya saja, tetapi juga sosok Umar Kayam sendiri.

Novel PP ini merupakan novel pertama atas dwiloginya dengan novel Jalan Menikung. Secara umum novel ini mengangkat tema budaya Jawa dengan perubahan zaman sebagai suatu kenyataan historis. Dalam penggambarannya dihadirkan tokoh-tokoh dari tiga generasi keluarga Sastrodarsono. Kurun waktu yang dijalaninya dimulai dari zaman Belanda, Jepang, hingga Orde Baru. Hal itu mengakibatkan munculnya perubahan-perubahan ideologi berdasarkan jiwa zamannya. Perubahan tersebut berakibat pada pudarnya konsep priayi (dehumanisasi) yang semula dianggap sebagai suatu yang ideal karena di dalamnya terdapat dialektika nilai.

Novel PP mengandung berbagai macam konsep atau pandangan tentang priayi dan dimunculkan dengan perspektif yang memandang sastra sebagai medan pertarungan dan pergeseran makna priayi. Dalam novel PP ini diduga pengaruh pergeseran makna priayi tersebut mampu menentukan alur, latar, dan karakter tokoh. Hal itu menjadikan pergeseran makna priayi menjadi saka utama dalam pembentukan struktur novel.

Munculnya berbagai macam makna priayi tersebut tentu saja membentuk dan mengakibatkan suatu pertentangan ideologi. Hal itu terlihat melalui munculnya pergeseran makna priayi pada tiap-tiap generasi dalam keluarga besar Sastrodarsono. Perubahan tersebut mengakibatkan suatu keterbukaan budaya. Keterbukaan itu terlihat pada sikap budaya Jawa yang pada mulanya sangat tertutup dengan mengedepankan nilai-nilai tradisi, tetapi setelah terjadi perubahan-perubahan dan pengaruh dari budaya luar sikap kebudayaannya menjadi terbuka.

Perubahan tersebut dalam novel PP digambarkan dengan jelas, misalnya terjadinya 
perubahan strata dari wong cilik menjadi priayi oleh tokoh Sastrodarsono. Selain itu, terlihat pula dalam proses perkawinan. Pada generasi Hardojo ataupun Noegroho, model perjodohan tidak lagi diterapkan padahal pada generasi Sastrodarsono model itu merupakan suatu adat yang harus dilaksanakan.

Dalam proses pergeseran makna priayi, diduga terdapat negosiasi-negosiasi antargenerasi yang bersifat dialektik. Hal itu terlihat dengan terjadinya mobilitas strata wong cilik menuju priayi. Proses tersebut dapat terjadi tentunya karena terdapat proses negosiasi antara wong cilik dengan priayi . Dalam proses perkawinan pun demikian, Hardojo anak dari Sastrodarsono tidak lagi mendapatkan jodoh berdasarkan pilihan orang tuanya, tetapi dia memilih sendiri pasangan hidupnya. Untuk memperoleh keinginan tersebut digunakan proses negosiasi antara Sastrodarsono dengan Hardojo. Proses-proses semacam ini terus dilakukan hingga mencapai konsensus dan kebenaran bersama dalam keluarga priayi.

Dalam mengkaji masalah-masalah pada novel PP karya Umar Kayam ini digunakan teori hegemoni Gramsci. Hal itu berdasarkan bahwa teori ini mampu menjelaskan dan mengungkapkan permasalahan-permasalahan seperti proses pergeseran makna priayi, status kelas, pandangan dunia kelas, gaya hidup, dan darma pengabdian kepada masyarakat.

\section{Membongkar Kepriayian antara Kebutuhan dan Gaya Hidup}

Seluruh kehidupan mendapatkan awal yang baru dan mulai berubah ketika seseorang memutuskan langkah yang diambil dalam kehidupan. Kenyataan bahwa pada generasi pertama, Sastrodarsono, sang pemula, menjadi guru adalah langkah pertama menuju kepriayian dengan surat keputusan di tangan sebagai pusat legitimasi semakin menjamin posisinya menjadi abdi gupermen dan keabdiannya itu pada gilirannya bukan menunjukkan suatu yang rendah, tetapi sesuatu yang terpandang/pusat.

Priayi menjadi lokus tempat kekuasaan itu bermain dan dipermainkan dari suatu pusat yang lain, sambil sesekali lingkungan priayi itu sendiri menjadi pusat kecil permainan kekuasaan lokal. Produktivitasnya tidak tinggi dan tidak selalu efektif, tetapi bisa dimanfaatkan, meskipun di dalam novel PP ditunjukkan bahwa hampir tidak bisa dimanipulasi oleh pusat-pusat lokal itu demi kepentingan lokal.

Pada gilirannya pusat itu bergerak karena kedarmaan seseorang yang bernama Lantip, generasi ketiga.

$$
\begin{aligned}
& \text { “"Kalau menurut kamu, apa arti } \\
& \text { kata priyayi itu, Tip?" } \\
& \text { 'Sesungguhnya saya tidak pernah } \\
& \text { tahu, Pakde. Kata itu tidak terlalu penting } \\
& \text { bagi saya" (Kayam, 1995:307). }
\end{aligned}
$$

Itulah percakapan antara Lantip dan Noegroho dalam novel Para Priyayi Umar Kayam bab terakhir. Tentu saja keduanya berbeda dalam cara berpikir. Lantip hidup dalam masyarakat semi-industrial, Noegroho dibesarkan dalam masyarakat agraris. Lantip lebih mengenal stratifikasi sosial berdasarkan kelas, maksudnya Lantip lebih mengenal dan memahami keadaan bahwa dalam hidup antara individu satu dengan yang lain terdapat perbedaan kelas sosial, misalnya antara priyayi dan bukan priyayi, antara atasan dan bawahan, dan sebagainya, sementara Noegroho dibesarkan dalam masyarakat berdasar status, ini berarti Noegroho lahir dalam lingkungan priyayi, atau lebih tepatnya dia seorang priyayi karena dilihat dari keturunannya.

Novel Para Priyayi yang sebenarnya merupakan suatu novel sejarah yang mengalami perubahan dalam pengisahannya. Seiring dengan perubahan yang ditampilkan sejalan pula dengan perubahan makna priyayi dalam novel Para Priyayi. Dalam novel ini Umar Kayam menciptakan tokoh yang berusaha menggeser makna priyayi yang menurut kebanyakan orang berarti status kelas bahwa dengan menyandang predikat sebagai seorang priyayi akan mampu mendapatkan status dalam kelas-kelas sosial, yaitu kelas priyayi, atau pengakuan masyarakat tentang kelas menengah elit birokrasi-yang kebanyakan priyayi dengan menduduki jabatan- 
jabatan pada lingkungan birokrasi atau gupermen akan mendapat pengakuan sebagai seorang priyayi, atau sekedar gaya hidup—bahwa dengan status priyayi seseorang akan lebih bergengsi dan diperhitungkan. Tokoh Lantip inilah yang justru nantinya akan mendefinisikan makna priyayi sejati menurut caranya sendiri.

Dalam novel ini yang menjadi tokoh adalah priyayi kecil, yaitu generasi pertama yang baru lepas dari status wong cilik. Leslie H Palmer (via Kartodirdjo, 1987) menggolongkan priyayi menjadi dua macam, yaitu priyayi luhur dan priyayi kecil. Priyayi luhur adalah priyayi yang sebenarnya dapat dilihat dari jabatan ayahnya, asal keturunan ibu dan istrinya, sedangkan priyayi kecil merupakan priyayi yang karena memiliki jabatan pada administrasi pemerintahan. Sementara itu, Koentjoroningrat (1984: 234) membagi golongan priyayi ke dalam priyayi pangrehpraja dan priyayi bukan pangrehpraja. Pengertian yang pertama ialah priyayi yang paling tinggi gengsinya, yaitu pejabat-pejabat pemerintah daerah, sedangkan priyayi bukan pangrehpraja merupakan golongan yang berasal dari wong cilik di kota yang berhasil mencapai kedudukan pegawai negeri melalui pendidikan. Stratifikasi atau kelas sosial nampak dalam kehidupan priyayi seperti tersebut di atas.

Dalam pada itu, priyayi yang ditampilkan dalam novel ini bukan priyayi jenis di atas, tetapi priyayi yang datang dari kalangan rendah, yaitu orang-orang yang ingin menjadi priyayi lewat suatu proses penghambaan (ngenger), mengabdi (nyumita), bukan karena warisan turun temurun, tetapi melalui perjuangan yang gigih dalam suatu proses yang panjang. Proses inilah yang disebut dengan mobilitas sosial.

\section{Mobilitas Sosial}

Tidak semua wong cilik menjadi priyayi, meskipun menjadi priyayi dicita-citakan oleh kebanyakan wong cilik. Satrodarsono bercitacita supaya anak-anaknya menjadi priyayi. Akan tetapi, cita-citanya itu baru terlaksana pada seorang cucunya, itu pun rupanya secara kebetulan. Kebetulan ayah Sastrodarsono sebagai petani berkesempatan mengerjakan tanah seorang priyayi (Asisten Wedana Kedungsimo). Jadi, dia ada motivasi kuat untuk menjadikan anaknya seorang priyayi, karena bergaul dengan priyayi.

Untuk dapat naik jenjang sosialnya, institusi yang ada ialah sekolah, ngenger, dan magang. Kejujuran, kesetiaan, keprigelan, adalah syarat-syarat yang harus dipenuhi bagi petani untuk menjadi seorang priyayi. Dalam novel Para Priyayi ini ayah Sastrodarsonolah yang praktis ngenger pada Ndoro Seten, maka anaknya mendapat kemudahan-kemudahan. "Kau mulai masuk dalam kalangan priyayi. Kau bukan lagi petani lagi", begitulah kata-kata Ndoro Seten kepada Darsono (Kayam, 1995: 38). Sebaliknya, seorang sponsor haruslah sembodo, murah hati. Hal ini ditunjukkan pada waktu ada pesta ngundhuh manten-nya Darsono, Ndoro Seten menyumbang pertunjukan wayang kulit komplit.

Begitu juga dengan Lantip, yang ngenger pada Ndoro Guru Sastrodarsono supaya jadi priyayi, dan ia sangat memuaskan. Dia bahkan lalu diangkat jadi cucu, dan oleh anak Sastrodarsono diangkat menjadi anak. Melalui sekolah, anak-anak laki-laki Sastrodarsono menjadi priyayi. Bagi anak perempuan mobilitas sosial mengikuti mobilitas sosial suami, Soemini mengikuti Harjono dan Susi mengikuti Noegroho. Setelah Indonesia merdeka satu anak Satrodarsono, Noegroho, menjadi tentara dengan pangkat terakhir kolonel di Jakarta, satu lagi jadi pegawai tinggi di Jakarta.

Dari beberapa mobilitas sosial yang dialami ternyata tidak melunturkan kerukunan dan solidaritas keluarga besar Satrodarsono. Dalam keadaan sulit., persoalan keluarga atau persoalan politik, ikatan keluarga besar itu masih efektif dalam menyelesaikan berbagai persoalan yang dihadapi.

\section{Stratifikasi Sosial}

Kesadaran mengenai perbedaan tingkat antara wong ndeso dan priyayi tertanam jauh dalam kesadaran orang. Suami-isteri Sastrodarsono tidak terlalu jauh mengambil jarak dengan Wage (Lantip) dan emboknya, tetapi Lantip mengenang, 
"'Tentu mereka tetap ndoro bagi kami dan kami adalah tetap wong ndeso...?

'Tapi, buat saya dia masih tetap anak desa Wanalawas. Eyangmu ini beginibegini masih raden mas lho, Le" (Kayam, 1995: 14).

Memang, kehormatan diri termasuk barang penting. Satrodarsono sehabis ditempeleng Jepang di kepala berkali-kali bilang, "Kepala! Nippong kurang ajar. Kepala dipukul. Kepala?' (Kayam, 1995: 130). Di sinilah harga diri sebagai priayi mengalami dehumanisasi oleh penguasa (Jepang) melalui kekerasan fisik yang menyingung harga diri priayi.

Untuk membedakan priyayi dengan orang desa, anak-anak Satrodarsono bersekolah di HIS (Wanagalih), sementara itu Lantip bersekolah di desa Karangdompol, selama lima tahun. Kadang-kadang kesadaran priyayi dan wong cilik itu sama, misalnya tentang politik. Tentang gupermen, ayah Sastrodarsono berkata,

"Kita semua rak sesungguhnya wong cilik saja to Le. Wong cilik yang diperintah gupermen. Lha sebagai wong cilik ya mesti manut, menurut aturan gupermen begitu" (Kayam, 1995: 61).

"Wong mertuamu itu priyayi gupermen tenan, abdi pemerintahan betul,...". Juga tentang raja Jawa. Satrodarsono berkata kepada anaknya Hardojo yang mengabdi pada Mangkunegaran bahwa sekalipun itu hanya kerajaan kecil, tapi raja itu raja bangsa sendiri. "Jangan sembrono. Raja itu malati, bertuah Le" (Kayam, 1995: 160).

Stratifikasi yang lain yang berbeda konteks dapat dilihat pada halaman 64-65, yang dijelaskan tentang dua macam priyayi: ksatria yang patuh dan ksatria yang mulia. Ksatria yang patuh ("penakut") adalah mereka yang punya sensibilitas "Sumantri ngenger", yaitu priyayipriyayi kawan kesukan-sejenis permainan kartu-Sastrodarsono, sedangkan ksatria mulia adalah Asisten Wedana Kedungsimo (setelah mengalami perubahan) dan Mantri Guru Mas Martoatmodjo. Satrodarsono sendiri berdiri di tengah-tengah, kemudian menjadi kesatria mulia (dengan mendirikan sekolah), kemudian menjadi kesatria patuh (dengan menutup sekolahnya).

Menjadi priyayi tidak hanya berarti sebuah peningkatan dalam status sosial, melainkan juga peningkatan kekuasaan. Hanya saja, sistem kekuasaan itu berlapis-lapis. Pada level negara, priyayi dapat menjadi hamba, menjadi abdi yang sama sekali tidak memiliki kekuasaan. Pada level desa, ia pun menjadi sosok yang dalam kadar tertentu, berada di bawah kekuasaan meski hanya dalam batas-batas tertentu, berada di bawah pengawasan kekuasaan negara. Kekuasaan priyayi baru menjadi penuh dalam lingkungan keluarganya, baik keluarga kecil maupun keluarga luas.

\section{Makna Priyayi}

Lalu apa sebenarnya makna priyayi itu. Bahwa seorang priyayi harus memiliki beberapa ciri, di antaranya ciri fisik dan ciri nonfisik. Ciri-ciri fisik priyayi rendahan (sebagaimana disiratkan oleh keluarga Satrodarsono) adalah tinggal di kota, dalam rumah gebyok, lepas dari pertanian (gaji, bukan upah atau untung), penataan meja makan, mandi air panas (bagi pensiunan), jalan-jalan pagi, bahasa Belanda sekalipun hanya een-twe-drie, kesukaan tayub, kendaraan dokar, sepeda, menyebut istri dengan dhik, perjodohan, pakaian Jawa (blangkon, jas tutup, kain batik), sebutan ndoro dan den bagus dari wong cilik, sebutan kamas/dimas/romo untuk sama-sama priyayi, dan suka wayang (Partokromo. Sumantri Ngenger) (Kartodirjo, 1987).

Selain itu seorang priyayi harus mempunyai ciri-ciri nonfisik seperti, mementingkan roso (mengendalikan perasaan), suka nembang (sekalipun ternyata hanya terbatas pada Wulangreh, Wedhatama, Tripama) setia (sebagaimana dianjurkan oleh Tripama), menghormati (mikul dhuwur mendhem jero), timbang rasa (tepa slira), sakmadya (tidak berlebihan), kepantasan tidak percaya takhayul, laku (ngelmu iku kelakone kanthi laku), prihatin sekedarnya (nglakoni, cegah dhahar lawan guling), dan melaksanakan darma (memayu hayuning bawana). Juga ketika menyelesaikan krisis kekuasaan dengan cara kembali ke duniadalam, kehalusan budi. 


\section{Abangan}

Priyayi adalah pemeluk Islam, sekalipun tidak menjalankan syariah. Ketika salah seorang anak Sastrodarsono, Hardojo, berpacaran dengan gadis Katholik, keluarga Sastrodarsono keberatan kalau Hardojo jadi Katholik (9399). Akan tetapi, jalan keluar kawin di burgerlijk stand disetujui. Mengenai syariat mereka berpendapat bahwa sembahyang dalam agama Islam itu terlalu wadhag, tidak bisa mencapai roso manunggaling kawo gusti (91). Anak-anak priyayi hanya dididik dengan dongeng dan cerita pewayangan meskipun tidak ada keberatan bagi mereka belajar mengaji. Rupanya pada kata abangan harus ditambah kata "Islam", menjadi Islam Abangan, sebab dalam suasana kritis dari mulut mereka masih bisa keluar al-Fatihah dan al-Ikblas (205).

Yang menjadikan mereka abangan ialah tidak banyak dikenalnya kisah-kisah Islam, tetapi cerita-cerita dari wayang saja yang dikenal, meskipun orang Islam sungguhan percaya bahwa cerita-cerita wayang kesemuanya ada dalam al-Quran (93). Juga kebiasaan minum arak dan kesukan dengan kartu pei tentu berbeda dengan kebiasaan santri.

\section{Ektended Family}

Seorang priyayi tidak pantas membiarkan anggota keluarga besarnya tidak terurus (15). Demikianlah, maka keluarga Sastrodarsono memelihara keponakan dari pihak lakilaki, Ngadiman, dan dari pihak perempuan keponakan-keponakan Sri dan Damin serta anak sepupunya, Soenandar. Mereka masih menampung cucu angkat, Wage alias Lantip, yang ternyata anak Soenandar. Inilah yang dimaksud dengan extended family, yaitu bertambahnya anggota keluarga dari keluarga yang lain, atau lebih tepatnya dalam bahasa Jawa disebut 'ngengoni sedulur'.

Keluarga Sastrodarsono menganggap bahwa kerepotan salah seorang anggota keluarga besar adalah juga kerepotan bersama. Demikianlah ketika suami Soemini jatuh cinta pada seorang penyayi keroncong kampungan, Sastrodarsono dan isteri ikut menyelesaikan. Juga ketika keluarga Noegroho ada kesulitan dengan Marie, suami istri Sastrodarsono, Lantip dan Harimurti ikut menangani. Demikian pula ketika Harimurti dan pacarnya masuk penjara dalam peristiwa G 30-S, Noegroho dan Lantip ikut mengurus. Tidak pernah persoalan-persoalan politik mengganggu hubungan keluarga besar. Harimurti tidak pernah mempermasalahkan keyakinan politik ayahnya (yang PNI), Pakdhe Noegroho yang purnawirawan ABRI dan kaya, serta Lantip. Keluarga besar juga tidak pernah mempersoalkan secara sungguh-sungguh keterlibatan Harimurti dalam Lekra.

\section{Priyayi di Mata Lantip}

Betapapun Umar Kayam berusaha sekuat tenaga untuk bersikap "deskriptif" dalam melukiskan tokoh-tokohnya, tetapi dari teks-teks yang ada terlihat bahwa simpatinya yang terutama tertuju pada kaum underdog. Semua tokoh-tokoh yang dianggap kalah selalu merupakan tokoh-tokoh yang paling menonjol dalam keluarganya. Selanjutnya, tokoh dengan latar belakang yang serba gelap kemudian muncul sebagai bintang sekaligus hero dalam keluarga dan bahkan dalam trah.

Tokoh Lantip dalam Para Priyayi, adalah seorang anak yang muncul dari latar belakang yang tak seorangpun ingin menceritakan: lahir diluar perkawinan yang sah, ibunya hidup dengan menjajakan tempe dari rumah ke rumah, sedangkan laki-laki yang telah menghamili ibunya, dikenal sebagai pencuri yang kemudian mati sebagai anggota sebuah geng rampok. Ayah Lantip, Soenandar, adalah salah seorang yang dititipkan oleh keluarganya pada keluarga Sastrodarsono, tetapi tidak bisa menyesuaikan diri dengan disiplin keluarga ini dan akhirnya terlempar keluar sebagai penjahat yang diburu polisi dan kemudian ditembak mati.

Lantip kemudian dititipkan juga pada keluarga Sastrodarsono, dan hanya mengetahui latar belakang ayahnya secara samar, yaitu kalau majikannya Sastrodarsono, marah-marah dan mulai memakinya sebagai anak gento, anak maling. Akan tetapi, Lantip bertumbuh dengan baik, bersekolah, dan kemudian diangkat anak 
oleh Hardojo adik Noegroho, dan menjadi saudara Harimurti, anak Hardojo. Keduanya melanjutkan studi ke jurusan sosial politik dan berhasil menyelesaikannya. Harimurti memilih aktif dalam organisasi kesenian PKI, sebaliknya Lantip adalah orang yang sekalipun tidak menyetujui sistem yang salah (entah itu diciptakan Stalin atau Amangkurat yang membunuh para santri), tetap percaya bahwa sistem adalah sesuatu yang diperlukan.

Adalah Lantip yang membereskan konflik dalam keluarga Soemini, ketika Harjono suami Soemini jatuh cinta pada seorang penyanyi keroncong. Lantip jugalah yang menjadi tokoh penyelamat ketika anak perempuan Noegroho, Marie, dihamili oleh seorang pemuda dari kalangan rendah berrnama Maridjan. Dia jugalah yang mencari dan kemudian menemukan dimana Gadis berada, setelah Gadis dan Hardojo ditangkap dan dipenjarakan sebagai aktivis organisasi kiri.

Dalam Para Priyayi ada tiga bab yang dipersembahkan kepada tokoh Lantip, seorang yang sekalipun telah diterima sebagai anggota resmi dalam keluarga priyayi, tetap dengan hormat kembali Ke Wanalawas, desa ibunya, untuk menabur kembang dimana, sambil menengok rumah Emboknya yang ditinggal kosong dan penuh sarang laba-laba. Lantip adalah seorang social commuter yang berhasil karena ketabahan menderita yang diperolehnya dari lingkungan bawah dapat dikombinasikan dengan baik kemungkinan dan kesempatan baru yang dibuka oleh lingkungan priyayi untuknya.

Dia adalah seorang yang dapat bolakbalik tanpa rasa canggung antara dua lingkungan sosial yang berlainan karena mampu meninggalkan kelemahan dari dua lingkungan dan memanfaatkan segi-seginya denGan baik. Kedua dunia telah mengajarkan padanya bahwa kebaikan dan kebudayaan tidak selalu ditentukan oleh asal-usul sosialnya. Ada halhal yang luhur dalam kalangan priyayi, tetapi juga ada kebiasaan-kebiasaan yang sebaiknya ditinggalkan. Demikian pun ada beberapa hal yang berasal dari lingkungan orang kecil yang memang harus ditinggalkan, tetapi ada berbagai nilai luhur yang layak dipertahankan.

Dialah orang yang mengerti secara praktis bahwa kebaikan dan keburukan adalah tanaman yang baru tumbuh berdampingan di dunia kita. Kebijaksanaan tak berarti lain daripada menerima kebaikan tanpa sekaligus menerima kejahatan, atau menolak kejahatan tanpa sekaligus juga menolak kebaikan. Tiap lingkungan sosial menanam kedua jenis tanaman ini, baik priyayi ataupun wong cilik. Karena itu Lantip adalah tokoh yang menjadi perlambang yang tegas tentang perbedaan yang harus dibuat antara apa yang sering disamakan. Bahwa status sosial tidaklah selalu identik dengan keluhuran budaya ataupun keagungan moral.

Ke-hero-an Lantip sebagai seorang priyayi dalam Para Priyayi ditunjukkan pada saat Lantip menyampaikan pidato abstraknya mengenai hakikat priyayi yang sejati, priyayi harus melaksanakan darma, dibayangkan oleh serangkaian peristiwa di hampIr seluruh cerita yang justru menunjukkan hal yang sebaliknya, ialah Lantip, priyayi sejati itu, sebagai seorang hamba yang begitu setia, begitu patuh. Segala kebaikannya bukanlah pelaksanaan drama karena drama bergerak dari atas ke bawah, melainkan sebagai pelaksanaan dari rasa kesetiaan, kepatuhan, dan rasa tahu dirinya sebagai orang yang berhutang budi besar pada keluarga Sastrodarsono yang menjadi majikannya. Kepriyayian seperti itu dibayangkan pula oleh tipe priyayi lainnya, priyayi yang tak bermoral seperti Sukendar, priyayi penjilat seperti juru pengawas sekolah, dan sebagainya. Kesemua itu harus hadir karena kehidupan ingin dihadirkan itu memang menuntut kehadirannya.

\section{Kesimpulan}

Perbedaan penafsiran makna priyayi antara trah Sastrodarsono cs dengan seorang Lantip menimbulkan sebuah pergeseran priyayi yang sama sekali berbeda dengan yang menjadi anggapan masyarakat luas. Dalam hal antara tesis yang memaknai pengertian priyayi sebagai status kelas, pandangan dunia kelas menengah elite birokrasi, atau sekedar gaya hidup, dengan antitesis yang mengandung pemahaman makna 
priyayi yang lebih mengedepankan darma dan pengabdian kepada masyarakat wong cilik, telah melahirkan sebuah sintesis makna priyayi seperti yang ditunjukkan Lantip, yang lebih memaknai priyayi dengan melihat sisi dalam dari seseorang sekalipun secara lahir dia sama sekali bukanlah seorang priyayi. Hal ini membuat PP menjadi sebuah pemahaman tentang pergeseran makna priyayi yang penuh falsafah.

\section{Daftar Pustaka}

Eagleton, Terry. 2002. Marxisme dan Kritik Sastra. Yogyakarta: Penerbit Sumbu.

Faruk. 2010. Pengantar Sosiologi Sastra: dari Strukturalisme Genetik sampai PostModernisme. Yogyakarta: Pustaka pelajar.

Faruk dan Ashadi Siregar (ed.). 2005. Umar Kayam Luar Dalam. Yogyakarta: Pinus.

Gramsci, Antonio. 1971. Selections from Prison Notebook, edited and translated by Quentin Hoare and Geoffray N Smith, London: Lawrenceadn Wishart.

Kartodirdjo, Sartono. 1987. Perkembangan peradaban Priyayi. Yogyakarta: Universitas Gajah Mada Yogyakarta Press.

Kayam, Umar. 1972. Seribu Kunang-Kunang di Manhattan. Jakarta: Pustaka Jaya. .1975. Sri Sumarah dan Bawnk. Jakarta: Pustaka Jaya. .1990. Mangan Ora Mangan Kumpul. Jakarta: Pustaka Utama Grafiti. .1995. Para Priyayi: Sebuah Novel. Jakarta: Pustaka Utama Grafiti. .1999. Jalan Menikung: Para Priyayi II. Jakarta: Pustaka Utama Grafiti.

Koentjaraningrat. 1984. Kebudayaan Jawa. Jakarta: Balai Pustaka.

Kuntowijoyo. 1997. Para Priyayi Sebagai Novel Sejarah. Makalah Seminar "Seni, Budaya, dan Ilmu Pengetahuan". Pusat Penelitian Kebudayaan dan Perubahan Sosial. Universitas Gajah Mada Yogyakarta.

Nurhadi. 2004. "Iblis Tidak Pernah Mati karya Seno Gumira Adjidarma Analisis Hegemoni Gramsci”. Tesis. Yogyakarta: Universitas Gadjah Mada (tidak diterbitkan).
Patria, Nezar dan Andi Arief. 1999. Antonio Gramsci:Negara dan Hegemoni. Yogyakarta: Pustaka Pelajar.

Ratna, Nyoman Kuta. 2009. Teori, Metode, dan Teknik Penelitian Sastra. Yogyakarta: Pustaka Pelajar.

Salam, Aprinus (ed.). 1998. Umar Kayam dan Jaring Semiotik. Yogyakarta: Pustaka Pelajar.

Simon, Roger. 2000. Gagasan-Gagasan Politik Gramsci. Terjemahan Kandani dan Imam Baehaki. Yogyakarta: Pustaka Pelajar.

Sugiono, Muhadi. 1999. Kritik Antonio Gramsci terhadap Pandangan Dunia Ketiga. Yogyakarta: Pustaka Pelajar. 